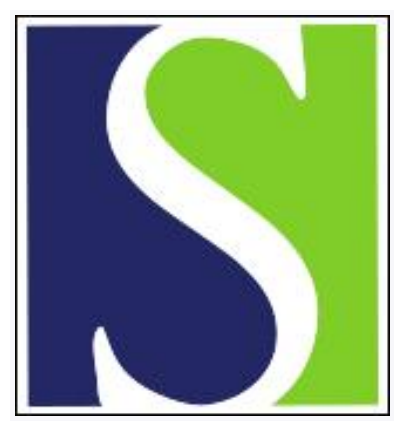

Scand J Work Environ Health 1995;21(4):293-295

https://doi.org/10.5271/sjweh.41

Issue date: Aug 1995

Primary liver cancer and renal cell carcinoma in laundry and dry-cleaning workers in Denmark

by Lynge $\mathrm{E}$, Carstensen $\mathrm{B}$, Andersen $\mathrm{O}$

Key terms: cancer incidence; control study; nested case-referent study; occupational health

This article in PubMed: www.ncbi.nlm.nih.gov/pubmed/8553005

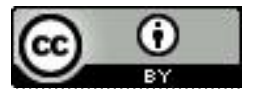




\title{
Primary liver cancer and renal cell carcinoma in laundry and dry-cleaning workers in Denmark
}

\author{
by Elsebeth Lynge, PhD, ${ }^{1}$ Bendix Carstensen ${ }^{1}$ Otto Andersen ${ }^{2}$
}

Lynge $E$, Carstensen $B$, Andersen 0. Primary liver cancer and renal cell carcinoma in laundry and dry-cleaning workers in Denmark. Scand J Work Environ Health 1995;21:293-5.

\begin{abstract}
Objectives Previous studies have shown an excess risk of primary liver cancer among women working in laundries and dry-cleaning shops in Denmark at the time of the census in 1970. During the period 1970-1987, 14 cases of primary liver cancer were observed (standardized mortality ratio $2.7,95 \%$ confidence interval $1.5-$ 4.5). A nested case-referent study was undertaken in order to classify laundry workers and dry-cleaning workers separately. According to hints in the literature, renal-cell carcinomas were also included in this analysis.

Methods Original census forms from 1970 were retrieved from the Danish National Record Office for the 17 cases with primary liver cancer and the 16 cases with renal-cell carcinoma and five matched referents per case.

Results All of the 17 patients with primary liver cancer worked in laundries in 1970 , whereas only $74 \%$ of the referents worked in laundries. Neither was the risk of renal-cell carcinoma associated with dry-cleaning work (relative risk $0.7,95 \%$ CI $0.2-2.6$ ).

Conclusions The excess risk of primary liver cancer observed for women working in laundries and drycleaning shops in Denmark is not likely to be explained by exposure to dry-cleaning solvents. Excessive alcohol consumption is not a likely explanation either, and the excess risk therefore remains unexplained.
\end{abstract}

Key terms cancer incidence, control study, nested case, occupational health.

Altogether 10600 laundry and dry-cleaning workers were recorded in the 1970 census in Denmark. A followup study of their cancer incidence from 1970 through 1980 showed an excess risk of primary liver cancer among the female workers (1). An excess risk was also observed in an update of the cohort study from 1981 through 1987 (2). All told, there were 14 observed cases of primary liver cancer among women, giving a standardized incidence ratio (SIR) of 2.7 [95\% confidence interval $(95 \% \mathrm{Cl}) 1.5-4.5]$. There were three observed cases of primary liver cancer in men, giving an SIR of $1.2(95 \%$ CI $0.3-3.5)$.

For the interpretation of the data it was, however, an obstacle that the codes for occupation and industry used in the 1970 census did not allow a distinction between laundries on one hand and dry-cleaning shops on the other. We therefore undertook a nested case-referent study in the cohort to reclassify the laundry and drycleaning workers into two separate groups. According to hints in the literature on a possible association with exposure to dry-cleaning solvents (3-4), cases of renalcell carcinoma were also included in this analysis.

1 Danish Cancer Society, Copenhagen, Denmark.

2 Danmarks Statistik, Copenhagen, Denmark.

\section{Material and methods}

The cohort comprised 10600 persons classified as working in "laundries, cleaning and dyeing" at the time of the 1970 census. These persons were either self-employed persons, family workers, laundry workers, or factory hands. They were followed for death, emigration, and incident cancer cases from the census date of 9 November 1970 through 8 November 1987. Altogether 17 cases (14 women and 3 men) of primary liver cancer and 16 cases ( 9 women and 7 men) of renal-cell carcinoma were observed during the follow-up period.

The referents were randomly selected from the cohort of 10600 persons classified as working in "laundries, cleaning and dyeing" at the time of the 1970 census. Five referents were selected for each case. The referents were matched with the case as to gender, 5-year age groups at the time of the census, and occupation (selfemployed person, family worker, laundry worker, or factory hand), and they were alive and living in Denmark on the date of diagnosis of the case. The personal identification numbers encrypted in the linked register were trans-

Reprint requests to: Dr Elsebeth Lynge, Danish Cancer Society, Strandboulevarden 49, DK-2100 København $\varnothing$, Denmark. 
formed back to the real numbers, and the addresses and census form numbers of each person were retrieved from the data files.

The original census forms for the 198 persons $(17+16$ cases and $85+80$ referents) were traced in the Danish National Record Office, where they are stored according to the address at the time of the census. In the 1970 census, the respondents were asked to give a fairly detailed description of their occupation and workplace. With the use of this free text, it was possible to code laundry workers and dry-cleaning workers separately.

The relative risk (RR) for each of the diseases among the dry-cleaning workers was calculated from the matched sets of cases and referents using conditional logistic regression (5).

\section{Results}

All of the 17 patients with primary liver cancer worked in laundries in 1970. Among the referents, 63 (74\%) worked in laundries and 20 (24\%) in dry-cleaning shops, and the census forms could not be traced for two (table 1).

Thirteen of the 16 patients with renal-cell carcinoma worked in laundries in 1970, and three worked in drycleaning shops. Among the referents, 59 (84\%) worked in laundries and $20(29 \%)$ in dry-cleaning shops, and the census form could not be traced for one.

Table 1. Incident cases of primary liver cancer and renal-cell carcinoma in 1970-1987 and matched referents among laundry and dry-cleaning workers in Denmark in 1970 by specific occupation.

\begin{tabular}{lcccc}
\hline & $\begin{array}{c}\text { Dry- } \\
\text { cleaning }\end{array}$ & Laundry & Unknown & Total \\
\hline Primary liver cancer & & & & \\
$\quad$ Men & & & & \\
$\quad$ Cases & - & 3 & - & 3 \\
$\quad$ Referents & 6 & 9 & - & 15 \\
Women & & & & \\
$\quad$ Cases & 14 & 54 & - & 14 \\
$\quad$ Referents & & & & 70 \\
Total & - & 17 & - & 17 \\
$\quad$ Cases & 20 & 63 & 2 & 85 \\
$\quad$ Referents & & & & \\
Renal-cell carcinoma & & & & \\
Men & 3 & 4 & - & 7 \\
$\quad$ Cases & 12 & 23 & - & 35 \\
$\quad$ Referents & & & & \\
Women & - & 9 & - & 9 \\
$\quad$ Cases & 8 & 36 & 1 & 45 \\
$\quad$ Referents & & & & \\
Total & 3 & 13 & - & 16 \\
$\quad$ Cases & 20 & 59 & 1 & 80 \\
$\quad$ Referents & & & & \\
\hline
\end{tabular}

The RR for renal-cell carcinoma among the drycleaning workers was 0.7 (95\% CI $0.2-2.6$ ) for the men and women together.

\section{Discussion}

The Danish cohort study of laundry and dry-cleaning workers was initiated after two case-referent studies from Finland indicated an excess risk of primary liver cancer for women exposed to chlorinated solvents $(6-7)$.

A fairly large number of women worked in laundries and dry-cleaning shops in Denmark in 1970, and tetrachloroethylene had been the predominant dry-cleaning solvent since the late 1950s (1). The excess risk of primary liver cancer observed in this cohort during two consecutive periods was hypothesized to be related to exposure to tetrachloroethylene.

However, the fact that the present nested case-referent study shows that none of the cases of primary liver cancer occurred in the dry-cleaning workers indicates that the excess risk of primary liver cancer observed in the total group of laundry and dry-cleaning workers is not likely to be caused by exposure to dry-cleaning solvents. However, it should be taken into account that only 17 cases of primary liver cancer were included in the present study and that the exposure classification was based only on the workplace descriptions given on the census forms.

These detailed Danish data are, however, in agreement with the outcome of other epidemiologic studies of dry-cleaning workers, for whom no excess risk of primary liver cancer was found (8-12).

The data do not support the observation of an excess risk of renal-cell carcinoma among dry-cleaning workers, which has been seen in some (3-4), but not all (13), previous studies. In addition, it should be kept in mind that the present study includes only 16 cases of renal-cell carcinoma and exposure information from census forms.

The excess risk of primary liver cancer among women, which is now known to be concentrated among laundry workers, remains a puzzle. The risk for laundry workers alone will be somewhat higher than the SIR value of 2.7 (95\% CI 1.5-4.5) found for the total group of laundry and dry-cleaning workers. It is highly unlikely that this excess was due to excessive alcohol drinking. A survey of alcohol consumption in Denmark in 1972 showed the use among female unskilled workers to be low in general, and only $2 \%$ of members from the union of laundry workers reported a daily consumption of beer, wine or liquor (14-15). The excess risk of liver cancer was also higher among the laundry workers than among women working in restaurants, bars and hotels at the time of the 1970 census (observed 8, SIR 1.4, 95\% CI $0.6-2.9$ ). Further elucidation of the risk of primary liver cancer for the Danish laundry workers will thus require a 
thorough investigation of the work exposures in laundries over time.

In conclusion, this nested case-referent study, based on the original census forms, showed that the excess risk of primary liver cancer seen among female laundry and dry-cleaning workers in Denmark is concentrated to laundry workers. Exposure to dry-cleaning solvents is therefore not a likely explanation for the excess risk. Excessive alcohol consumption is not a likely explanation either. The excess risk observed in two consecutive periods thus remains unexplained.

\section{References}

1. Lynge $\mathrm{E}$, Thygesen L. Primary liver cancer among women in laundry and dry-cleaning work in Denmark. Scand J Work Environ Health 1990;16:108-12.

2. Lynge E. Danish Cancer Registry as a resource of occupational research. J Occup Med 1994;36:1169-73.

3. McCredie, M, Stewart JH. Risk factors for kidney cancer in New South Wales: IV. occupation. Br J Ind Med 1993;50: 349-54.

4. Mellemgaard A, Engholm G, McLaughlin JK, Olsen JH. Occupational risk factors for renal-cell carcinoma in Denmark. Scand J Work Environ Health 1994;20:160-5.

5. Breslow NE, Day NE. Statistical methods in cancer research. The analysis of case-control studies. Lyon: International Agency for Research on Cancer (IARC), 1980. IARC scientific publications, no 32, vol 1 .

6. Hernberg S, Korkala M-L, Asikainen U, Riala R. Primary liver cancer and exposure to solvents. Int Arch Occup Environ Health 1984;54:147 -53.

7. Hernberg S, Kauppinen T, Riala R, Korkala M-L, Asikainen
U. Increased risk for primary liver cancer among women exposed to solvents. Scand J Work Environ Health 1988;14: $356-65$.

8. Ruder AM, Ward EM, Brown DP. Cancer mortality in female and male dry-cleaning workers. J Occup Med 1994;36:86774.

9. Blair A, Stewart PA, Tolbert PE, Grauman D, Moran FX, Vaught $J$, et al. Cancer and other causes of death among a cohort of dry cleaners. Br J Ind Med 1990;47:162-8.

10. Duh R-W, Asal NR. Mortality among laundry and dry-cleaning workers in Oklahoma. Am J Public Health 1984;74: 1278 - 80

11. Katz RM, Jowett D. Female laundry and dry-cleaning workers in Wisconsin: a mortality analysis. Am $\mathbf{J}$ Public Health 1981;71:305-7.

12. Malker H, Weiner J. Cancer-miljöregisteret: exempel på utnyttjande av register-epidemiologi inom arbetsmiljöområdet [Cancer environment register: examples of use of register based epidemiology in occupational health]. Stockholm: Arbetarskyddsverket, 1994. Arbete och Hälsa 1984:9.

13. Asal NR, Geyer JR, Risser DR, Lee ET, Kadamani S, Cherng N. Risk factors in renal cell carcinoma: II. medical history, occupation, multivariate analysis, and conclusions. Cancer Detect Prev 1988;13:263-79.

14. Arbejdsmiljøgruppen af 1972 . Arbejdsmiljøunders $\varnothing g e l s e n:$ rygsmerter, stress og høreskader [Work environment survey: back pains, stress and hearing loss]. København: Arbejdsmiljøgruppen af 1972, 1974. Rapport no 2.

15. Dansk Data Arkiv. Arbejdsmiljøundersøgelsen 1973 [Work environment survey 1973]. Odense (Denmark): Dansk Data Arkiv, 1982.

Received for publication: 20 January 1995 